done in this institution, and similar institutions; that is, to create in the minds of the leaders of the profession what Sir Walter Morley Fletcher would call "The Religion of Research". Lord Moynihan said he hoped that the date would not be far distant when those who are to serve upon the teaching staffs of hospitals throughout Great Britain will be permeated by "The Religion of Research", and in time to come all members of the teaching staffs will themselves have undergone, in institutions similar to this, a discipline of research.

In concluding, Lord Moynihan said that by his constant thought Dr. Wellcome has done as much as any man has ever done in Great Britain to make it possible to advance both the science and the art of medicine.

By placing the Museum of Medical Science, including tropical medicine and hygiene, and the Historical Medical Museum under one roof, there is no doubt that in London there will be a combination which will be unequalled in the world.

The associated Physiological Research Laboratories will remain at Langley Court, Beckenham, and the Field Entomological Laboratory at Claremont, Esher.

\section{Plant Breeding in Germany.}

THE acceptance by Dr. Baur of the invitation of the Royal Horticultural Society to give the Masters Lectures in 1931 has resulted in the publication, in the Journal of the Horticultural Society, vol. 56 , Part II, of two lectures which contain, in the first place, a most effective short statement of the present position of evolution, and in the second, a very interesting summary of the work in plant breeding that is being carried out, under Dr. Baur's direction, in the Kaiser Wilhelm Institut für Züchtungsforschung at Müncheberg.

Dr. Baur concludes that the experimental study of genetics has shown clearly that "inheritance of acquired characters in the sense of Lamarck does not exist". He argues that the main cause of what Darwin called hereditary variation is the combination of characters provided for by biparental inheritance, but differs from Lotsy because he considers that such variations are too limited to supply the needs of progressive evolution. Continued breeding of Antirrhinum has led him to the conclusion that the frequency of mutation is no less than $1 \cdot 3-7$ per cent, though such mutations are mainly recessive and therefore only distinguished on extensive and continued breeding trials. Most of these mutations are small, and a striking mutation is usually associated with loss of vitality. Dr. Baur concludes that through the selection of small mutations the differentiation of species out of parent species can be explained, and that wider differences may gradually arise because two such new forms, as they become separated by an increasing number of such 'small-point mutations', tend also to become infertile to one another.

Dr. Baur's account of the work of the Kaiser Wilhelm Institute is full of interest. The extensive breeding work, coupled with patient testing, which permits the isolation of a lupin free from poisonous alkaloids, after a million and a half plants have been examined, is a striking example of selection work. The recombination of Mendelian characters is carried out on normal lines, but on an extensive scale, with wheats, grapes, etc.; whilst now experiments are proceeding with attempts to induce variations artificially by chemical methods, as has been done so successfully in recent years by $\mathrm{X}$-rays.

\section{University and Educational Intelligence.}

CAMBridge.-The Vice-Chancellor has received a letter from the Trustees of the British Museum offering the sum of $£ 2000$ for the use of the Scott Polar Research Institute. This sum represents the greater part of the balance remaining of the sum which was subscribed to meet the cost of publishing the scientific results of Capt. Scott's Terra Nova expedition.

London.-The title of professor has been conferred on the following: Mr. F. W. Twort (bacteriology), in respect of the post held by him at the Brown Animal Sanatory Institution; Dr. H. A. Harris (clinical anatomy), in respect of the posts held by him at University College and University College Hospital Medical School; Dr. F. A. P. Aveling (psychology), in respect of the post held by him at King's College

The title of reader in eugenics has been conferred on Miss E. M. Elderton, in respect of the post held by her at University College.

OXFord.-On Nov. 17, Congregation passed a decree recording the grateful thanks of the University to Prof. J. Mark Baldwin, for a gift of $£ 1000$ for the capital endowment of the Edward Bagnall Poulton Fund, established for the encouragement of research in the subject of evolution. This fund has already been of much service in assisting work of the kind indicated.

At the same meeting of Congregation the thanks of the University were accorded to the Royal Astronomical Society for a generous gift to the Lewis Evans Collection of a set of more than fifty astronomical and mathematical instruments.

SheFFIELD.-Prof. J. H. Andrew, professor of metallurgy at the Royal Technical College, Glasgow, has been appointed to the chair of metallurgy in the University in succession to Prof. C. H. Desch, who has been appointed superintendent of the Department of Metallurgy at the National Physical Laboratory.

ON Nov. 29 the Cinema Hall, which is maintained by the Empire Marketing Board at the Imperial Institute, South Kensington, reopened with a series of cinematograph displays, many of which are travel films of geographical interest. In future an admission charge of one penny is being made for each session. Monthly programmes of the films and lectures may be obtained on the payment of two shillings, being subscription for one year.

THE following scholarships will be offered by the Institution of Naval Architects Scholarships for competition in 1932: Naval architecture, Martell scholarship ( $£ 130$ a year for 3 years) ; Denny scholarship ( $£ 75$ a year for 4 years): Marine engineering, Parsons scholarship (£150 a year for 3 years); Denny scholarship (£75 a year for 4 years). The Denny scholarships are open to boys less than nineteen years of age from public or secondary schools who have not yet begun their apprenticeship, and are tenable at the University of Glasgow. The remaining scholarships are open to apprentices less than twentythree years of age, and are tenable at the Royal Naval College, Greenwich, the University of Glasgow, Armstrong College (University of Durham), the University of Liverpool, and the City and Guilds (Engineering) College, London. Particulars may be obtained from the Secretary of the Institution of Naval Architects, 2 Adam Street, Adelphi, London, W.C.2. 